\title{
Mitral valve prolapse, aortic compliance, and skin collagen in joint hypermobility syndrome
}

\author{
CLIVE E HANDLER, ^ ANNE CHILD, $\dagger$ NICHOLAS D LIGHT, \\ DEBORAH E DORRANCE $\dagger$
}

\begin{abstract}
From the Departments of *Cardiology and $\nmid$ Rheumatology, Guy's Hospital, London; and the $\ddagger A F R C$ Meat Research Institutes Langford, Avon
\end{abstract}

SUMMARY Mitral valve prolapse was sought clinically and with phonocardiography and M mode and sector echocardiography in 15 women aged 22-57 years with joint hypermobility syndrome. The type III:III + I collagen ratio was measured in skin biopsy specimens and was found to be raised in seven of 10 patients sampled. Thirteen patients had increased aortic wall compliance measured by the continuous wave Doppler ultrasound technique. Ten (67\%) patients had mitral valve prolapse shown by auscultatory signs or echocardiography or both-a prevalence at least three times greater than that in the general adult population.

It is concluded that if the abnormality of collagen biosynthesis found in skin biopsy samples in these patients is also present in their mitral valve tissue this may predispose them to prolapse of the valve.

The primary mitral valve prolapse syndrome is one of the commonest cardiac abnormalities, being present in 4-21\% of the adult population. ${ }^{12}$ Most of those affected are symptom free and have a good prognosis, ${ }^{3}$ but sudden death, ${ }^{45}$ infective endocarditis, ${ }^{6}$ spontaneous chordal rupture, and progressive mitral regurgitation ${ }^{7}$ are rare complications and make this an important condition to recognise. The subject has been well reviewed. ${ }^{28-12}$

The synonymous term, floppy mitral valve syndrome, emphasises the well established structural abnormality of the valve leaflets, although the molecular basis for this defect remains unclear. The main structural abnormality of the valve leaflets in primary mitral valve prolapse consists of myxomatous degeneration and disruption of the pars fibrosa and there is dilatation of the mitral annulus. ${ }^{212}$

The association of mitral valve prolapse with certain inherited diseases (secondary mitral valve prolapse) including the Marfan syndrome, ${ }^{13}$ the Ehlers-Danlos syndrome, ${ }^{14}$ and osteogenesis imperfecta, ${ }^{15}$ lends support to the hypothesis that mitral valve prolapse may be due to abnormalities in the

Requests for reprints to Dr Clive E Handler, Department of Cardiology, Guy's Hospital, London SE1 9RT.

Accepted for publication 22 July 1985 production or structure of collagen. Such changes have been shown to occur in these conditions. ${ }^{16}$

The hypermobility syndrome is a sex influenced usually dominantly inherited disorder of collagen production characterised by non-inflammatory joint pain associated with generalised joint laxity. ${ }^{17}$ Mitral valve prolapse is present in about a third of cases, ${ }^{1819}$ providing further evidence that a systemic abnormality of collagen may be associated with mitral valve prolapse. There is, at present, little information on this connection. One study of the family of a patient with type IV Ehlers-Danlos syndrome has shown a consistent association of mitral valve prolapse and abnormally low type III collagen production. ${ }^{20} \mathrm{~A}$ more recent study, however, has shown an increased proportion of type III collagen in floppy mitral valve tissue compared with normal controls. ${ }^{21}$

The purpose of this study, therefore, was to assess the frequency of mitral valve prolapse among a group of patients who had evidence of a generalised connective tissue disorder and examine the link with the ratio of III:III + I collagen types in skin biopsy specimens.

\section{Patients and methods}

Fifteen patients (all female, with an age range of $22-57$, mean 39 years) were selected from a group of 
72 consecutive patients ( 62 women, 10 men) with joint hypermobility and joint pain attending Guy's Hospital rheumatology department. Radiographs of the affected joints were normal, and all patients were seronegative.

These 15 patients were selected because they had clinical evidence of generalised connective tissue weakness. Eleven of the 15 patients had skeletal signs (arm span 3 inches $(7.62 \mathrm{~cm}$ ) greater than height, scoliosis, pectus excavatum, high palate, antimongoloid slant to the eyes, long fingers). Eight had dermatological signs (thin, hyperextensible skin, striae, easy bruisability), and eight had eye signs (hypertelorism, epicanthic folds, redundant upper eyelids, severe myopia, strabismus). In addition, a clear family history of joint hypermobility associated with pain in a first degree relative, most often a mother or sister, was obtained from all but one patient (case 4).

\section{JOINT HYPERMOBILITY}

All the patients were examined by one of us (AHC), and joint mobility was graded by the hypermobility score of Beighton and Horan. ${ }^{22}$ The scoring system is as follows: (a) passive hyperextension of the fifth metacarpophalangeal joint to $90^{\circ}$ scores 1 for each hand; $(b)$ passive apposition of the thumb to the volar aspect of the forearm scores 1 for each thumb; (c) passive hyperextension of the elbow to more than $10^{\circ}$ scores 1 for each arm; $(d)$ passive hyperextension of the knees to beyond $10^{\circ}$ scores 1 for each leg; $(e)$ placing hands flat on floor by flexing spine while maintaining knees straight scores 1 . The maximum score is 9 . A score of $\geqslant 3$ indicates a widespread hypermobility of the joints.

\section{COLLAGEN III:III + I RATIO ASSESSMENT}

Collagen types I and III were measured by a modification of the method described by Light. ${ }^{23}$ After local spray anaesthesia, small, full thickness, scissor biopsy specimens of forearm skin tissue were taken and frozen immediately at $-70^{\circ} \mathrm{C}$ and then dissolved in formic acid. Collagen types I and III were measured by sodium dodecyl sulphate polyacrylamide gel electrophoresis after digestion of skin samples with cyanogen bromide.

\section{AORTIC WALL COMPLIANCE}

Collagen comprises nearly half of the content of the aortic media and makes the greatest contribution to the tensile strength of the wall. The distensibility of the aortic wall is measurable by Doppler shift continuous wave ultrasound signals ${ }^{24}$ and is directly related to vessel compliance. This is defined as the fractional distension of diastolic lumen diameter per unit of pulse pressure: $C=(\Delta \mathrm{D} / \mathrm{D}) / \Delta \mathrm{P}$, where $\mathrm{C}$ is the vessel compliance and $\Delta \mathrm{D}$ is the increase in diameter of the lumen $\mathrm{D}$ produced by an increment of pressure $\mathbf{P}$. Compliance is usually expressed as $\mathrm{C} \%$ per $10 \mathrm{~mm} \mathrm{Hg}$ change in pulse pressure. Thus the distensibility of the aortic wall, which depends on its tensile strength, is directly related to the vessel's compliance.

The optimum method for measuring aortic compliance requires a system that is capable of measuring the change in luminal diameter produced by changes in pressure along the full length of the aorta. This takes into account variation in collagen content of the aortic wall and variable aortic tethering.

Accurate measurement of aortic pressures is not easily obtained except by direct aortic catheterisation. Pulsed wave echo ultrasonography allows the measurement of aortic compliance at given sites but not along the aortic length.

Aortic compliance cannot be measured directly by the continuous wave Doppler technique but it is possible to measure the characteristic pulse wave velocity by recording Doppler shift signals generated by reflection of the ultrasound beam from passing red blood cells at two simultaneously insonated sites on the aortic pathway. The puse wave velocity (PWV) equals $\mathrm{L} / \mathrm{T}$; where $\mathrm{L}$ is the distance between the two sites, $T$ the delay time for the same heart beat at sites L apart between the start of systolic upswing of the blood velocity Doppler shift pulses.

The characteristic pulse wave velocity is dependent on the blood density and the elastic modulus of volume distensibility of the artery wall per unit length. ${ }^{24}$ The variability and reproducibility of this method have been studied in 900 normal volunteers. ${ }^{25}$ Normal values for aortic compliance are low in the neonate, rise gradually to a peak at 10 years of age, and then fall gradually to adult levels. These studies have shown that the maximum standard deviation from the mean in each cohort is $10 \%$ and that there is no appreciable variation in aortic compliance with blood pressure changes within physiological limits. ${ }^{25}$ The normal range is taken as 100 (2 SD) (that is $80-120 \%$ ) (Fig. 1).

Aortic compliance is not corrected for blood pressure as there is little variation in aortic compliance with change in blood pressure at physiological pressures. ${ }^{25}$ It has also been shown that the maximum variability of aortic compliance throughout the day is $9.1 \%$. Hourly aortic compliance was measured during the day in six symptom free adults (four men, two women, aged 20-26 years) who continued their usual daily activities ( $\mathrm{S}$ Kontis, personal communication). Only variations $>10 \%$ were regarded as abnormal in this study - that is values above $130 \%$ or below $70 \%$. 
Table Summary of results and clinical data

\begin{tabular}{|c|c|c|c|c|c|c|c|c|c|}
\hline \multirow[b]{2}{*}{ Patient } & \multirow[b]{2}{*}{ Age (yr) } & \multirow[b]{2}{*}{$\begin{array}{l}\text { foint } \\
\text { hypermobility } \\
(\max =9)\end{array}$} & \multirow[b]{2}{*}{$\begin{array}{l}\text { Aortic } \\
\text { compliance } \\
(\%)\end{array}$} & \multirow[b]{2}{*}{$\begin{array}{l}\text { Collagen } \\
I I I: I I I+I\end{array}$} & \multicolumn{4}{|c|}{ Cardiograpy } & \multirow[b]{2}{*}{ Symptoms } \\
\hline & & & & & Echo & Phono & Auscultation & $E C G$ & \\
\hline $\begin{array}{l}1 \\
2 \\
3 \\
4 \\
5 \\
6 \\
7 \\
8 \\
9\end{array}$ & $\begin{array}{l}22 \\
27 \\
28 \\
29 \\
31 \\
31 \\
33 \\
38 \\
44\end{array}$ & $\begin{array}{l}8 \\
3 \\
5 \\
6 \\
2 \\
5 \\
5 \\
1 \\
5\end{array}$ & $\begin{array}{l}100 \\
167 \\
145 \\
138 \\
118 \\
157 \\
130 \\
148 \\
144\end{array}$ & $\begin{array}{l}27 \\
24 \\
27 \\
28 \\
25 \\
\frac{29}{30}\end{array}$ & $\begin{array}{l}\text { MVP } \\
\text { MVP } \\
\mathbf{N} \\
\mathbf{N} \\
\mathbf{N} \\
\mathbf{N} \\
\text { MVP } \\
\text { MVP } \\
\mathbf{N}\end{array}$ & $\begin{array}{l}\text { MSC } \\
\text { MSC } \\
\mathbf{N} \\
\mathbf{N} \\
\mathbf{N} \\
\mathbf{N} \\
\mathbf{N} \\
\text { MSC } \\
\text { MSC }\end{array}$ & $\begin{array}{l}\text { MSC } \\
\text { MSC } \\
\mathbf{N} \\
\mathbf{N} \\
\mathbf{N} \\
\mathbf{N} \\
\mathbf{N} \\
\text { MSC } \\
\text { MSC }\end{array}$ & $\begin{array}{l}\mathbf{N} \\
\mathbf{N} \\
\mathbf{N} \\
\mathbf{N} \\
\mathbf{N} \\
\mathbf{N} \\
\mathbf{N} \\
\mathbf{N} \\
\text { T inv, II, } \\
\quad \text { III, aVF }\end{array}$ & $\begin{array}{l}\text { Palpitation } \\
\text { Dyspnoea } \\
\overline{-} \\
\text { ACP } \\
= \\
\overline{-} \\
\text { Palpitation }\end{array}$ \\
\hline $\begin{array}{l}10 \\
11\end{array}$ & $\begin{array}{l}45 \\
50\end{array}$ & $\begin{array}{l}5 \\
1\end{array}$ & $\begin{array}{l}141 \\
143\end{array}$ & - & $\begin{array}{l}\mathbf{N} \\
\mathbf{M V P}\end{array}$ & $\begin{array}{l}\mathbf{N} \\
\mathbf{N}\end{array}$ & $\begin{array}{l}\mathbf{N} \\
\mathbf{N}\end{array}$ & $\begin{array}{l}\mathrm{N} \\
\mathrm{T} \text { inv, }\end{array}$ & - \\
\hline 12 & 52 & 7 & 149 & - & MVP & MSC & MSC & $\begin{array}{l}\text { 1st deg } \\
\text { HB, T inv, } \\
\text { II, III }\end{array}$ & ACP \\
\hline $\begin{array}{l}13 \\
14 \\
15\end{array}$ & $\begin{array}{l}53 \\
53 \\
53\end{array}$ & $\begin{array}{l}4 \\
7 \\
7\end{array}$ & $\begin{array}{l}139 \\
169 \\
217\end{array}$ & $\begin{array}{l}31 \\
33 \\
46\end{array}$ & $\begin{array}{l}\text { MVP } \\
\text { MVP } \\
\text { MVP }\end{array}$ & $\begin{array}{l}\text { MSC } \\
\text { MSC } \\
\mathbf{N}\end{array}$ & $\begin{array}{l}\text { MSC } \\
\mathbf{N} \\
\mathbf{N}\end{array}$ & $\begin{array}{l}\mathbf{N} \\
\mathbf{N} \\
\mathbf{N}\end{array}$ & $\begin{array}{l}\text { Palpitation } \\
\text { Dyspnoea } \\
\text { - }\end{array}$ \\
\hline
\end{tabular}

ECG, electrocardiogram; ACP, atypical chest pain; MVP, mitral valve prolapse; MSC, midsystolic click; HB, heart block; T inv, T wave inversion. Aortic compliance: normal range $80-120 \%$, mean $145 \%$ in these patients.

Collagen III:III + I: normal range $23-27 \%$, mean $30 \%$ in these patients.

METHOD OF MEASURING AORTIC COMPLIANCE The pulse wave velocity was measured with the patient supine and unsedated. A hand held probe from a $4 \mathrm{MHz}$ bidirectional Doppler ultrasound velocimeter (Sonicaid, Vasoflow 2 BV 980) was placed in the left supraclavicular fossa over the subclavian artery, pointing medially. Simultaneously, a probe from an identical $4 \mathrm{MHz}$ bi-directional Doppler ultrasound velocimeter was placed over the abdominal aorta at the level of the umbilicus, just proximal to the aortoiliac bifurcation. The instantaneous spectrum of blood velocities in the vessel lumen at each site was monitored by recording the Doppler shift in frequency of the backscattered ultrasound signals on to stereomagnetic tape. The Doppler ultrasound velocimeters were modified by means of frequency domain processing to display both forward and reverse flow on each channel. The distance (L) was taken from the midpoint on the medial side of the sternal notch to the transducer site on the abdomen. From cadaver studies this has been shown to be within 5\% of the effective aortic pathway. ${ }^{26}$ Brachial blood pressure was recorded at the end of the measurement.

The recorded audio frequency Doppler shift signals from the two sites were simultaneously spectrally analysed on separate channels of a spectrum analyser (Doptek). A hard copy printout of the resultant sonogram on ultraviolet light sensitive paper (Kodak Linagraph 1801) was obtained by means of a fibreoptic recorder (Medilec SOR 1002). The delay time ( $T$ ) between the start of the systolic velocity upstroke for each pulse was measured with an electronic digitiser (Summagraphics, Bitpad) and a microcomputer (Commodore Pet type 8032). Care was taken to obtain the value of $\mathrm{T}$ from the systolic foot to foot separation of the proximal and distal waveforms, and $\mathrm{T}$ was averaged for at least 20 pulses to minimise change in the aortic compliance caused by pressure fluctuations with respiration. Aortic compliance was then calculated from the equation:

$$
\mathrm{C} \% \text { per } 10 \mathrm{~mm} \mathrm{Hg}(1.33 \mathrm{kPa})=66.7(\mathrm{~T} / \mathrm{L})
$$

Aortic compliance (C) was expressed as a percentage of the normal value found per $10 \mathrm{~mm} \mathrm{Hg}$ change in pulse pressure. $^{24}$

\section{CARDIAC ASSESSMENT}

All the patients were examined by one of us (CEH). Auscultatory signs of mitral valve prolapse were sought with patients being examined supine, in the left lateral position, and standing. This was supplemented by a phonocardiographic examination with a Smith Kline Instruments diagnostic module $\mathbf{P} / \mathbf{N}$ 8544-9000, which was performed with the patient in the $40^{\circ}$ left lateral position and breathing gently.

A standard 12 lead electrocardiogram was obtained in all patients. $M$ mode and sector echocardiography were performed by a standardised technique with the patient in the partial left lateral position. We used an Ekoline sector 2 (Smith Kline Instruments) with a $2 \cdot 1 \mathrm{MHz} 90^{\circ}$ transducer. 


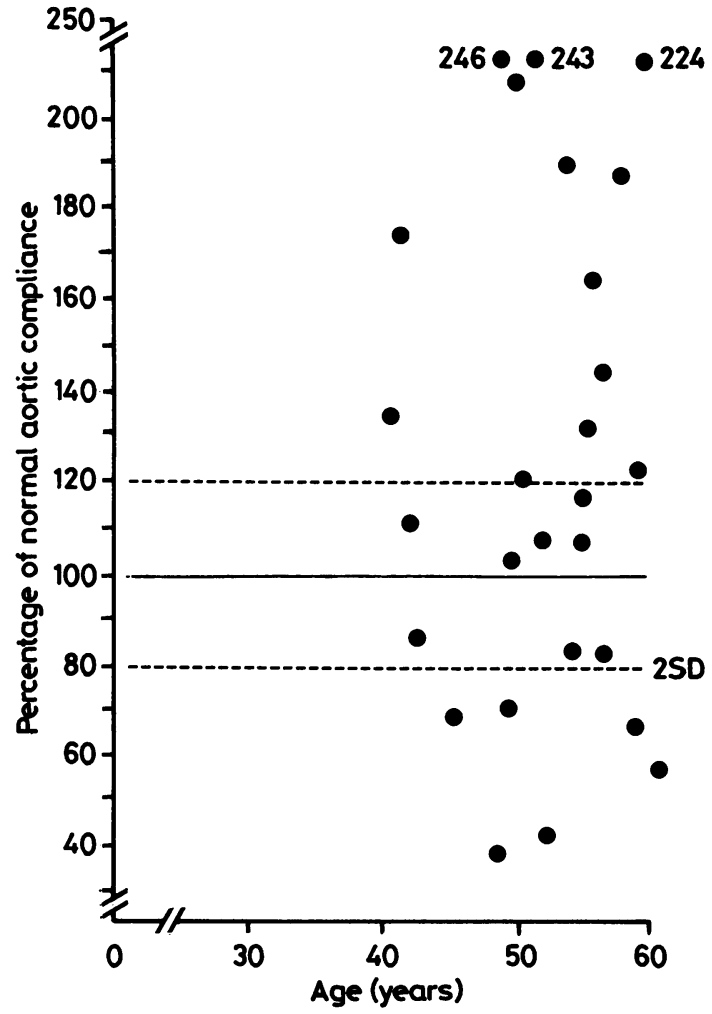

Fig. 1 Aortic compliance (\%) of individual subjects plotted against age (years). Mean (solid line) and 2 SD (broken lines) for aortic compliance previously measured in normal subjects are shown.

The $M$ mode echocardiographic diagnosis of mitral valve prolapse was made by showing mid to late systolic displacement of one or both leaflets at least 2 $\mathrm{mm}$ below the line joining the point of valve closure in systole (C) to the point of valve opening in diastole (D); or a pansystolic posterior displacement of at least $3 \mathrm{~mm}$ below the line joining $C$ and $D$ with the least displacement occurring in mid systole. ${ }^{27}$ The criterion for diagnosis of mitral valve prolapse on the sector scan was protrusion of a portion of one or both mitral valve leaflets across the plane of the atrioventricular ring into the left atrium during systole. ${ }^{2829}$ Mitral valve prolapse was diagnosed if either the $M$ mode or sector scan echocardiographic criteria were fulfilled.

\section{Results}

The Table summarises the results and clinical data.

\section{AORTIC COMPLIANCE}

Thirteen of the 15 patients had a significantly increased aortic compliance (Table). The two highest values were found in the oldest patients, whereas the
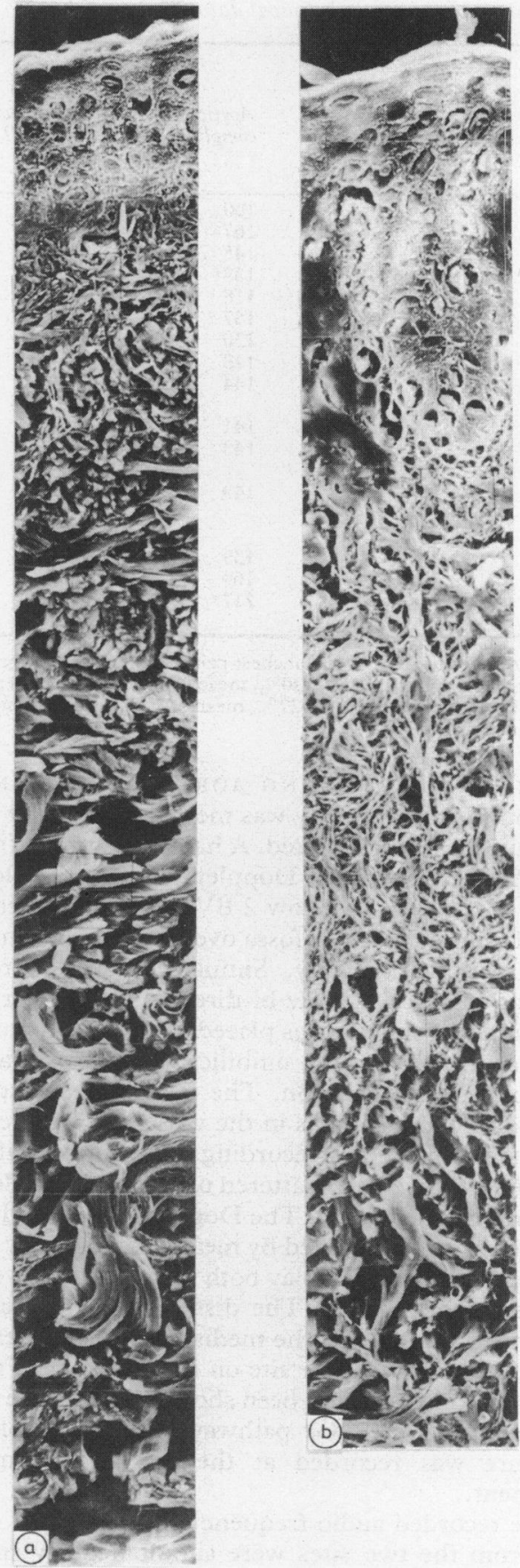

Fig. 2 Scanning electron micrograph of a skin biopsy specimen from an age and sex matched control (a) and $a$ patient (b) (case 13) with mitral valve prolapse, raised collagen type III $: I I I+I$ ratio in the skin, and increased aortic compliance. Case 13 had decreased skin thickness, a decreased proportion of thick collagen fibres, and an increased proportion of fine disorganised collagen fibres. 


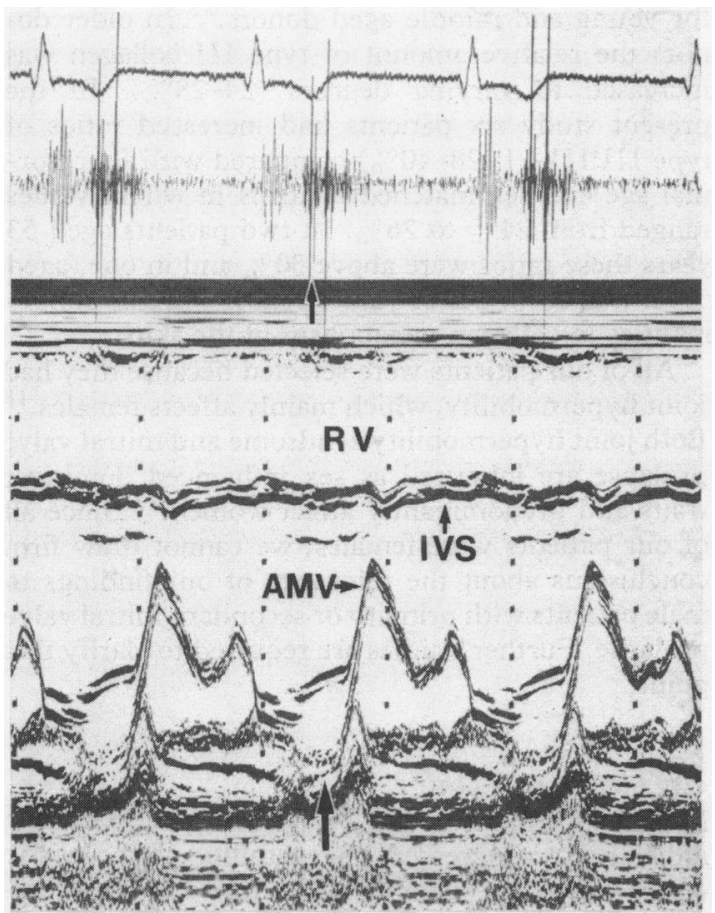

Fig. 3 Surface electrocardiogram (top), phonocardiogram (middle), and $M$ mode echocardiogram (bottom) from a patient (case 12) who had clinical, echocardiographic, and phonocardiographic features of mitral valve prolapse and $T$ wave inversion and first degree heart block (PR interval $0.24 \mathrm{~s}$ ) on a resting 12 lead electrocardiogram. Lower arrow indicates prolapse of the posterior mitral valve leaflet. $R V$, right ventricle; IVS, intraventricular septum; $A M V$, anterior mitral valve leaflet.

youngest patient had a normal value. There was no significant correlation of aortic compliance either with age or with skin collagen type III or types $\mathrm{III}+\mathrm{I}$.

\section{SKIN COLLAGEN III:III+I RATIO}

In six of the 10 patients sampled the ratio of III:III + I collagen in the skin was increased. In the three patients aged more than 53 years these ratios were $31 \%, 33 \%$, and $46 \%$. Samples from the three youngest patients (aged under 28 years) were within normal limits. Skin collagen ratio III : III $+I$ increased significantly with increasing age $(p<0.01)$.

Fig. 2 shows a typical scanning electron micrograph of a skin biopsy specimen from a patient (case 13) with mitral valve prolapse, raised type III:III + I collagen ratio in the skin, and increased aortic compliance, compared with a skin biopsy specimen from a normal age and sex matched control. The micrograph of case 13 shows decreased skin thickness, a decreased proportion of thick collagen fibres, and an increased proportion of fine disorganised collagen fibres.

\section{CARDIAC FINDINGS}

Five patients had both auscultatory and echocardiographic features typical of mitral valve prolapse. One patient had a mid systolic click on phonocardiography and mitral valve prolapse on echocardiography but no abnormality detected by auscultation. One patient had a click on phonocardiography and on auscultation but had a normal echocardiogram. Three patients had mitral valve prolapse diagnosed only by echocardiography. Thus 10 of the 15 patients had mitral valve prolapse diagnosed by one or more of the criteria used and in nine of these patients echocardiography was positive. Fig. 3 shows a representative $M$ mode echocardiogram (from case 1).

Three patients had an abnormal electrocardiogram, and all three had mitral valve prolapse. The electrocardiographic abnormalities consisted of non-specific $T$ wave inversion in the inferior leads and, in one patient, first degree heart block. Seven patients had cardiac symptoms (mainly palpitation and atypical chest pain), and one of these did not have mitral valve prolapse. Three patients with echocardiographic evidence of mitral valve prolapse were symptom free.

\section{Discussion}

Our findings are consistent with those from other studies in which an increased frequency of secondary mitral valve prolapse has been found in patients with certain connective tissue diseases ${ }^{12-16}$ and an abnormality of collagen. The results also suggest that a raised generalised ratio of collagen types III:III + I may be important in the pathogenesis of this condition, which has been attributed to a disorganisation of the lamina fibrosa of the mitral valve cusps. $^{30}$

Our results accord with those of a recent study by Cole et al on normal and floppy valves from necropsy and surgical material. ${ }^{21}$ They found a greatly increased amount of type III collagen and a smaller increase in type I collagen in tissue from the floppy valve.

Evidence for the heterogeneity of collagen deficiency in this condition has come from Hammer et al, who reported a deficiency of types III and V collagen in a floppy mitral valve. ${ }^{31}$

An earlier study by Jaffe et al on the family of a proband with classic type IV Ehlers-Danlos syndrome also provides evidence for an abnormality of type III collagen production in patients with co- 


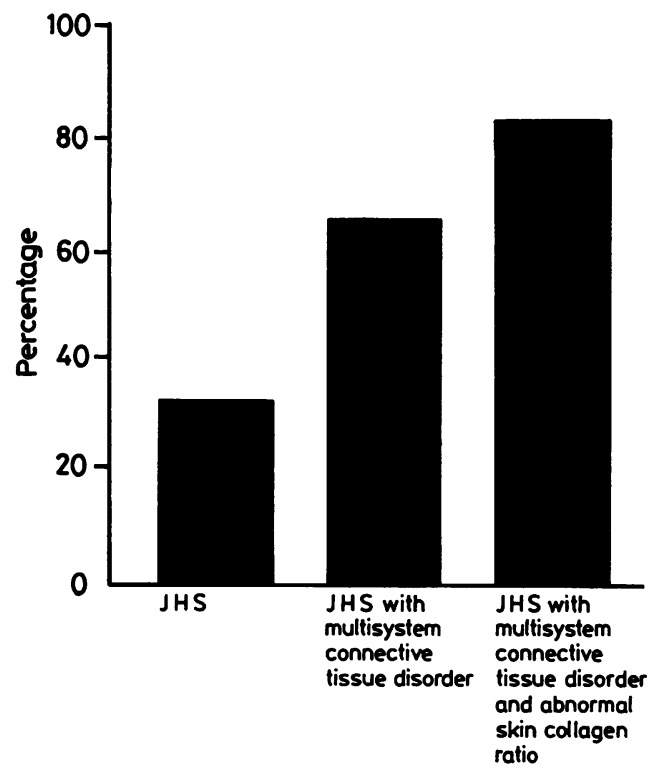

Fig. 4 Histogram showing the prevalence of mitral valve prolapse (\%) reportea in joint hypermobility syndrome $(\mathfrak{F H S}),{ }^{18}$ in joint hypermobility syndrome with additional evidence of connective tissue disorder, ${ }^{19}$ and the frequency found in the present study. The frequency of mitral valve prolapse in patients with joint hypermobility, multisystem connective tissue disorder, and abnormal skin collagen is at least three times that in the general adult female population.

existing mitral valve prolapse. ${ }^{20}$ They found a lower type III collagen production in those patients with mitral valve prolapse than in family members who did not have mitral valve prolapse. An increased prevalence of mitral valve prolapse has been found in patients with osteogenesis imperfecta ${ }^{15}$ where collagen type $I$ is abnormal. These reports and our own data strongly suggest heterogenous abnormalities of collagen biosynthesis in patients with mitral valve prolapse.

\section{SKIN COLLAGEN RATIOS}

Skin collagen ratios were measured in only 10 of our 15 patients. When we were establishing the microassay used in this study, the collagen extracts from four age matched controls and patients $4,8,10,11$, and 12 were run on a gel and the results were technically unsatisfactory. This is a clear disadvantage of working with small samples as there may not be enough collagen peptides to repeat a run. These five patients could not undergo repeat biopsy because they had been entered into a drug trial which affected their skin collagen ratios. In a previous study, however, the ratio of collagen types III:III + I in abdominal skin from normal donors ranging in age from 3 months to 92 years was shown to be $18-21 \%$ for young and middle aged donors. ${ }^{32}$ In older donors the relative amount of type III collagen was increased to varying degrees $(24-28 \%)$. In the present study six patients had increased ratios of type III:III + I $(28-40 \%)$ compared with four normal age and sex matched controls in whom values ranged from $24 \%$ to $26 \%$. In two patients aged 53 years these ratios were above $30 \%$ and in one (aged 57 ) it was $46 \%$. These values reflect extreme abnormalities in collagen metabolism in the skin.

All of our patients were selected because they had joint hypermobility, which mainly affects females. ${ }^{18}$ Both joint hypermobility syndrome and mitral valve prolapse are inherited as sex influenced dominant traits and predominantly affect women. ${ }^{33}$ Since all of our patients were females, we cannot draw firm conclusions about the relevance of our findings to male patients with primary or secondary mitral valve prolapse. Further studies are required to clarify this point.

\section{AORTIC COMPLIANCE}

Most of our patients had a raised aortic compliance indicating an increased distensibility of the aortic wall. This is presumably related to abnormal collagen in the media. Abnormally high values for aortic compliance have been reported in various inherited connective tissue disorders including those with a known collagen abnormality. ${ }^{34}$ The raised values in our patients confirm the presence of a generalised connective tissue disorder.

The normal aortic compliance in the youngest patient may reflect the variability of expression of the gene determining this disease, producing lax ligaments and joint capsules while leaving the aorta relatively unaffected. It would be interesting to remeasure the compliance in this patient at a later date to assess whether her mitral valve prolapse has progressed.

In a previous blind study the aortic compliance of nine patients with Ehlers-Danlos syndrome type IV was found to be significantly increased. ${ }^{35}$ The more severely affected patients with very low type III collagen production had the highest compliance values. In a second blind study aortic compliance was shown to be increased in six out of 10 patients with ruptured intracranial aneurysm. ${ }^{36}$ Four of the six patients had low production of type III collagen in skin fibroblasts.

Joint hypermobility syndrome, in which there is an apparent deficiency of collagen type I with overproduction of collagen type III, is a third instance of a collagen deficiency disease in which structural cardiovascular weakness (here of the mitral valve) is associated with increased aortic compliance. 
CARDIAC FINDINGS

One of our patients (case 9) had auscultatory and phonocardiographic signs of mitral valve prolapse and a normal $M$ mode and sector echocardiogram. Most investigators have found that about $10 \%$ of patients with typical auscultatory findings do not have prolapse on echocardiography and vice versa. ${ }^{2}$ This weak association between physical signs and echocardiographic features of mitral valve prolapse is corroborated by the Framingham study. ${ }^{37}$ It is also conceivable that one or more of our patients had echonegative and silent mitral valve prolapse. None of our patients had murmurs, and this is perhaps a little surprising since soft systolic murmurs may be present in apparently healthy women. ${ }^{38}$

Certain electrocardiographic abnormalities, including non-specific $T$ wave changes, are well recognised in patients with mitral valve prolapse. ${ }^{1039}$ All three patients with abnormal electrocardiograms in this study had mitral valve prolapse.

Sudden unexpected death is a rare but recognised complication of secondary mitral valve prolapse. $\mathrm{Re}-$ cently, Pocock et al reported a young patient with mitral valve prolapse who died suddenly. ${ }^{40}$ They suggested that she had ventricular fibrillation which was probably related to multifocal premature ventricular contractions. They have assembled sixteen other cases of sudden death in patients with mitral valve prolapse, and although they emphasise that the frequency of sudden death is low, they stress the importance of identifying the small group of patients at higher risk and of managing them appropriately.

Because the risks of sudden death and other complications, including those requiring valve replacement, appear small, physicians usually reassure most patients who have only echocardiographic evidence of mitral valve prolapse but may keep them under periodic review. Antibiotic prophylaxis against infective endocarditis is, at present, usually recommended only for those patients who have systolic murmurs, ${ }^{41}$ but this approach is not universal. The results from this study suggest that all patients with hypermobility syndrome and signs of generalised connective tissue deficiency should have careful clinical asessment with echocardiography because the frequency of mitral valve prolapse is likely to be high (Fig. 4). Antibiotic prophylaxis should be seriously considered in patients shown to have mitral valve prolapse, since endocarditis can develop (albeit rarely) in patients who have clicks and no murmurs. ${ }^{4142}$

It is not yet known whether those patients in whom complications develop are more likely to have a generalised connective tissue disorder and a more severely abnormal mitral valve structure or both than those with a good prognosis.
The results of our study suggest a link between secondary mitral valve prolapse and abnormal skin collagen. It would be of interest and possible clinical importance to assess collagen characteristics in mitral valve tissue from patients with hypermobility syndromes and also to assess collagen characteristics in skin and, whenever possible, mitral valve tissue from patients with primary mitral valve prolapse. If there is a common abnormality of collagen in the skin and mitral valve tissue, then it is possible that this could be of relevance in those patients who develop progressive mitral regurgitation or abrupt severe mitral regurgitation due to chordal rupture.

We thank Dr Mary Dyson, Department of Anatomy, Guy's Hospital, for interpreting the electronmicrographs of the skin and Dr Rodney Grahame, Department of Rheumatology, Guy's Hospital, for allowing us to study his patients.

CEH was supported by the Medical Research Council, AC was supported by the British Heart Foundation, the Arthritis and Rheumatism Council, and Corda, and DED was supported by the South East Thames Research Committee.

\section{References}

1 Markiewicz W, Stoner J, London E, Hunt SA, Popp RL. Mitral valve prolapse in one hundred presumably healthy young females. Circulation 1973; 53: 464-73.

2 Jerasaty RM. Mitral valve prolapse. New York: Raven Press, 1979.

3 Bisset GS III, Schwartz DC, Meyer RA, James FW, Kaplan S. Clinical spectrum and long-term follow-up of isolated mitral valve prolapse in 119 children. Circulation 1980; 62: 423-9.

4 Appelblatt NH, Willis PW, Lenhart JA, Shulman JI, Walton JA Jr. Ten to 40 year follow-up of 69 patients with systolic click with or without late systolic murmur [Abstract]. Am F Cardiol 1975; 35: 119.

5 Barlow JB, Bosman CK, Pocock WA, Marchand P. Late systolic murmurs and non-ejection ("mid-late") systolic clicks. An analysis of 90 patients. Br Heart $\mathcal{F}$ 1968; 30: 203-18.

6 Corrigall D, Bolen J, Hancock EW, Popp RL. Mitral valve prolapse and infective endocarditis. $A m \mathcal{F}$ Med 1977; 63: 215-22.

7 Goodman D, Kimbiris D, Linhart JW. Chordae tendineae rupture complicating the systolic click-late systolic murmur syndrome. Am f Cardiol 1974; 33: 681-4.

8 Barlow JB, Pocock WA. The problem of non-ejection systolic clicks and associated mitral systolic murmurs, emphasis on the billowing mitral leaflet syndrome. $\mathrm{Am}$ Heart f 1975; 90: 636-55.

9 Malcolm AD, Boughner DR, Kostuk WJ, Ahuja SP. Clinical features and investigative findings in presence of mitral leaflet prolapse: study of 85 consecutive patients. Br Heart $\mathcal{F}$ 1976; 38: 244-56.

10 Devereux RB, Perloff JK, Reichek N, Josephson ME. 
Mitral valve prolapse Circulation 1976; 54: 3-14.

11 Leatham A, Brigden W. Mild mitral regurgitation and the mitral prolapse fiasco. Am Heart $\mathcal{f}$ 1980; 99: 659-64.

12 Malcolm AD. Mitral valve prolapse associated with other disorders: causal coincidence, common link, or fundamental genetic disturbance? Br Heart f 1985; 53: 353-62.

13 Brown OR, DeMots H, Kloster FE, Roberts A, Menashe VD, Beals RK. Aortic root dilatation and mitral valve prolapse in Marfan's syndrome. Circulation 1975; 52: 651-7.

14 Cabeen WR Jr, Reza MJ, Kovick RB, Stern MS. Mitral valve prolapse and conduction defects in EhlersDanlos syndrome. Arch Intern Med 1977; 137: 1227-31.

15 Wood SJ, Thomas J, Braimbridge MV. Mitral valve disease and open heart surgery in osteogenesis imperfecta tarda. Br Heart $\mathcal{F}$ 1973; 35: 103-6.

16 Pope FM, Nicholls AC, Dorling J, Webb J. Molecular abnormalities of collagen: a review. $\mathcal{F} R$ Soc Med 1983; 76: 1050-62.

17 Child A, Symmons D, Light N, Dyson M, Dorrance $\mathrm{D}$, Grahame R. Collagen deficiency in joint hypermobility syndrome [Abstract]. $\mathrm{Br} \mathcal{F}$ Rheumatol 1984; 23: 134.

18 Grahame R, Edwards JC, Pitcher D, Gabell A, Harvey WA. A clinical and echocardiographic study of patients with the hypermobility syndrome. Ann Rheum Dis 1981; 40: 541-6.

19 Pitcher D, Grahame R. Mitral valve prolapse and joint hypermobility: evidence for a systemic connective tissue abnormality? Ann Rheum Dis 1982; 41: 352-4.

20 Jaffe AS, Geltman EM, Rodey GE, Uitto J. Mitral valve prolapse: a consistent manifestation of type IV Ehlers-Danlos syndrome. The pathogenetic role of the abnormal production of type III collagen. Circulation 1981; 64: 121-5.

21 Cole WG, Chan D, Hickey AJ, Wilcken DEL. Collagen composition of normal and myxomatous human mitral heart valves Biochem $\mathcal{F} 1984$; 219: 451-60.

22 Beighton P, Horan S. Orthopaedic aspects of the Ehlers-Danlos Syndrome. f Bone foint Surg $(\mathrm{Br})$ 1969; 51: 444-53.

23 Light ND. Estimation of Types I and III collagens in whole tissue by quantitation of $\mathrm{CNBr}$ peptides on SDS polyacrylamide gels. Biochim Biophys Acta 1982; 702: 30-6.

24 Laogun AA, Gosling RG. In vivo arterial compliance in man. Clin Phys Physiol Meas 1982; 3: 201-12.

25 Laogun AA. University of London, 1977. PhD Thesis.

26 Frank O. Die Theorie der Pulswellen. Zeitschrift für Biologie 1926; 85: 91-130.

27 DeMaria AN, King JF, Bogren HG, Lies JE, Mason DT. The variable spectrum of echocardiographic manifestation of the mitral valve prolapse syndrome. Circulation 1974; 50: 33-41.
28 Child JS, Skorton DJ, Taylor RD, et al. M mode and cross-sectional echocardiographic features of flail posterior mitral leaflets. Am $\mathcal{f}$ Cardiol 1979; 44: 1383-90.

29 Alpert MA, Carney RJ, Flaker GC, Sanfelippo JF, Webel RR, Kelly DL. Sensitivity and specificity of two-dimensional echocardiographic signs of mitral valve prolapse. Am f Cardiol 1984; 54: 792-6.

30 Davies MJ, Moore BP, Braimbridge ML. The floppy mitral valve: study of incidence, pathology and complications in surgical, necropsy, and forensic material. $\mathrm{Br}$ Heart f 1978; 40: 468-81.

31 Hammer D, Leier CV, Baba N, Vasko JS, Wooley CF, Pinnell SR. Altered collagen composition in a prolapsing mitral valve with ruptured chordae tendineae. Am F Med 1979; 67: 863-6.

32 Lovell CR, Smolenski KA, Duance VC, Light ND, Young S, Dyson M. A study of type I and type III collagen content and fiber distribution in normal human skin during ageing. $\mathcal{F}$ Invest Dermatol (In press).

33 Devereux RB, Brown WT, Kramer-Fox R, Sachs I. Inheritance of mitral valve prolapse: effect of age and sex on gene expression. Ann Intern Med 1982; 97: 826-32.

34 Child AH, Dorrance DE, Jay B, Pope FM, Jones RB, Gosling RG. Aortic compliance in connective tissue disorders affecting the eye. Ophthalmic Paediatrics and Genetics 1981; 1: 59-76.

35 Neil-Dwyer G, Child AH, Dorrance DE, Pope FM, Bartlett J. Aortic compliance in patients with ruptured intracranial aneurysms [Letter]. Lancet 1983; i: 939-40.

36 Pope FM, Nicholls AC, Narcisi P, Bartlett J, NeilDwyer G, Doshi B. Some patients with cerebral aneurysms are deficient in type III collagen. Lancet 1981; i: $973-5$.

37 Savage DD, Devereux RB, Garrison RJ, et al. Mitral valve prolapse in the general population. 2. Clinical features: The Framingham Study. Am Heart $f$ 1983; 106: 77-81.

38 Craige E. Echocardiography and other noninvasive techniques to elucidate heart murmurs. In: Braunwald E, ed. Heart disease- a textbook of cardiovascular medicine. 2nd ed. Philadelphia: WB Saunders, 1984: 68-145.

39 Lobstein HP, Horowitz LD, Curry GC, Mullins CB. Electrocardiographic abnormalities in the mitral clickmurmur syndrome. N Engl f Med 1973; 289: 127-31.

40 Pocock WA, Bosman CK, Chesler E, Barlow JB, Edwards JE. Sudden death in primary mitral valve prolapse. Am Heart F 1984; 107: 378-82.

41 Hickey AJ, MacMahon SW, Wilcken DEL. Mitral valve prolapse and bacterial endocarditis: when is antibiotic prophylaxis necessary? Am Heart $\mathcal{f}$ 1985; 109: 431-5.

42 Lachman AS, Bramwell-Jones DM, Lakier JB, Pocock WA, Barlow JB. Infective endocarditis in the billowing mitral leaflet syndrome. Br Heart $\mathcal{F} 1975$; 37: 326-30. 